\title{
Chronic Disease in the Elderly: Spirituality and Coping*
}

DOENÇA CRÔNICA NO IDOSO: ESPIRITUALIDADE E ENFRENTAMENTO

ENFERMEDAD CRÓNICA EN EL ANCIANO: ESPIRITUALIDAD Y AFRONTAMIENTO

\author{
Ana Carolina Albiero Leandro da Rocha1, Suely Itsuko Ciosak ${ }^{2}$
}

\begin{abstract}
This is an exploratory study using a qualitative methodology which aims to identify and understand the role of spirituality in the management of the chronic disease in the elderly. The analysis revealed the following central themes: multidimensional impact of chronic illness, coping and expectations of the elderly. Regarding coping with chronic illness, the individual coping, social support and religiosity / spirituality / faith were analyzed. The results showed the changes brought about by the diagnosis of chronic disease and its implications for the adaptation to the new way of life. The management of these changes is complex and many factors influence positively and negatively in order to deal with the new condition. The results showed that religiosity/spirituality/ faith interferes positively in addressing the obstacles and difficulties of life, strengthening the resilience of the patient, thus improving their quality of life.
\end{abstract}

\section{RESUMO}

Trata-se de um estudo exploratório, com metodologia qualitativa que teve como objetivo identificar e compreender o papel da espiritualidade no manejo da doença crônica do idoso. A análise dos discursos resultou nos seguintes temas centrais: impacto multidimensional da doença crônica, enfrentamento e expectativas dos idosos. Com relação ao enfrentamento da doença crônica, foram analisados o enfrentamento individual, o suporte social e a espiritualidade/religiosidade/fé. Os resultados evidenciaram as mudanças trazidas pelo diagnóstico da doença crônica e suas implicações na adaptação ao novo modo de vida. O manejo destas alterações é complexo e diversos fatores influenciam positivamente e negativamente no modo de lidar com a nova condição. Os resultados mostraram que a espiritualidade/religiosidade/ fé interfere de maneira positiva no enfrentamento dos obstáculos e dificuldades da vida, fortalece a resiliência do paciente, melhorando assim, sua qualidade de vida.

\author{
DESCRITORES \\ Espiritualidade \\ Doença crônica \\ Idoso \\ Adaptação psicológica
}

\section{RESUMEN}

Se trata de un estudio exploratorio utilizando una metodología cualitativa que tiene como objetivo identificar y comprender el papel de la espiritualidad en la gestión de las enfermedades crónicas en los ancianos. El análisis reveló los siguientes temas centrales: el impacto multidimensional de la enfermedad crónica, afrontamiento y expectativas de las personas mayores. En lo que respecta a hacer frente a las enfermedades crónicas, el duelo individual, el apoyo social y la religiosidad / espiritualidad / fe fueron analizados. Los resultados mostraron los cambios introducidos por el diagnóstico de la enfermedad crónica y sus implicaciones para la adaptación a la nueva forma de vida. La gestión de estos cambios es compleja y muchos factores influyen positiva y negativamente con el fin de hacer frente a la nueva condición. Los resultados mostraron que la religiosidad/espiritualidad/fe interfiere positivamente en el tratamiento de los obstáculos y las dificultades de la vida, fortalecendo la capacidad de recuperación del paciente, mejorando así su calidad de vida.

\section{DESCRIPTORES \\ Espiritualidad \\ Enfermedad crónica \\ Anciano \\ Adaptación psicológica}

"Research extracted from the Master's Dissertation "Spirituality in the Management of Chronic Disease" presented to obtain the title of Master of Science at the Graduate Program in Nursing in 2011. ${ }^{1}$ Master of Science, School of Nursing, University of São Paulo, Graduate Program in Nursing. ${ }^{2}$ Associate Professor, Department of Community Health Nursing, School of Nursing, University of São Paulo. 


\section{INTRODUCTION}

Aging and spirituality are areas of multidisciplinary interest, therefore, topics for discussion are found in several areas. Beliefs and personal spirituality, as components of health are old concepts, but at the same time, these are new and unfamiliar topics to the health team on daily health care. ${ }^{(1)}$

Concepts such as spirituality, religiosity, hope and social support end up overlapping each other and despite daily use, religiosity and spirituality are not synonymous, thus religion is a form of expression of spirituality.

The mechanism by which spirituality influences health and well-being is unclear and the relationship between spirituality and chronic disease is not well understood, although researchers and clinicians believe that spirituality and health have important connections. What is known is that chronic diseases interrupts many areas of one's life, which can lead to depression, irritability and loss of hope. ${ }^{(2)}$

Spirituality can be used as a coping strategy for critical situations of people's lives, since it can increase the sense of purpose and meaning of life, which are associated with greater resistance to stress, which is related to diseases. ${ }^{(3)}$

Personal beliefs give meaning to situations of suffering in life, for example, chronic diseases is referred to as both a "spiritual encounter" as a physical and emotional experience. The search for a purpose in life and the experience of connection with God and with others, seems to be an important way to cope with chronic disease. ${ }^{(4)}$

Considering spirituality as part of the concept of human health and its impact on living with chronic diseases, the present study aimed to identify and understand the role of spirituality in the management of chronic disease in the elderly.

\section{METHOD}

This is an exploratory study, with a qualitative character. A qualitative methodology was needed to understand the subjective results found in the research. The nonrandom sample consisted of 20 elderly patients from a multidisciplinary consultation in a specialized institute in the care for the elderly in São Paulo, Brazil, in the year 2011. Inclusion criteria were: age greater or equal to 60 years, being aware and informed to have chronic disease, being able to communicate verbally and comply with study participation, regardless of gender.

For data collection, a form was elaborated which consisted of a semi-structured interview developed with the goal of understanding the mechanism of spirituality in the process of coping with chronic disease.

All study participants were informed of the research objectives, agreed with the recording of the interviews, confidentiality and anonymity was guaranteed. The participation occurred from signing the Consent Form. The study was approved by the Ethics Committee of the School of Nursing at University of São Paulo, the institution sponsoring the study, thus obeying the regulations of Decree 196/96 of the Brazilian National Health Council, which recommends principles for the development of research involving human beings.

\section{RESULTS}

From discourses resulting from interviews and their repeated readings, content analysis emerged, classified into three central themes that revealed the multidimensional impact of chronic diseases, coping and expectations of the participants, these topics were adopted as objects of analysis. From each central themes, thematic units emerged and units of record that can be viewed in Table 1.

Table 1 - Distribution of units of record, thematic units and central themes identified. São paulo, 2011.

\begin{tabular}{lll}
\hline Central Themes & Thematic Units & Units of Records \\
\hline $\begin{array}{l}\text { Multidimensional } \\
\text { impact of chronic } \\
\text { disease }\end{array}$ & $\begin{array}{l}\text { Lifestyle } \\
\text { Emotional } \\
\text { Socioeconomic } \\
\text { Personal coping }\end{array}$ & $\begin{array}{l}\text { Food } \\
\text { Limitation/aggravation }\end{array}$ \\
& Social support & \\
Coping & Spirituality/religion/faith & $\begin{array}{l}\text { Cope } \\
\text { Increased } \\
\text { Conserved } \\
\text { Decreased }\end{array}$ \\
& & \\
Patient's & Regarding health & \\
expectations & Regarding meaning of life & \\
\hline
\end{tabular}

The most prevalent chronic disease in the elderly interviewed was hypertension, being mentioned by $45 \%$ of participants, followed by diabetes mellitus reported by $35 \%$ of the elderly interviewed. For $30 \%$ of the study participants, changes in food impacted the lifestyle after diagnosis of the chronic disease.

For $65 \%$, of the elderly, chronic disease represented much more than decrease in physical activity, increased dependence to perform various functions, even basic activities of daily living. For patients who reported enjoying going out, walking and travelling, have "gotten sick" represented an important limitation, as they come to rely on family members for these activities.

In $65 \%$ of the discourses there were demonstrations of anxiety anguish and sadness arising from the changes caused by the disease. In the present study sample, 70\% of subjects were completely independent and held various recreational and work activities without difficulty. In contrast, some participants were experiencing conditions of increasing dependence due to the chronic disease. 


\section{DISCUSSION}

\section{MULTIDIMENSIONAL IMPACT OF CHRONIC DISEASE}

Receiving the diagnosis of chronic disease and adapting their lives to disease and treatment require strength of willpower and determination of the patient. ${ }^{(5)}$

By analyzing the discourses in this light, three thematic units emerged: Lifestyle, emotional impact and socioeconomic impact.

For some participants, when asked, responded that chronic disease did not cause changes in their lives. These discourses demonstrate the active adaptability of human adversity and brings to light the concept of resilience.

Individuals who, during their life, experience difficulties and barriers, develop this ability to deal with the psychological impact caused by critical moments and aging consequently increase their resilience.

For $80 \%$ of elderly of this research, their children, grandchild and partners were responsible for giving meaning to life and also the main source of strength to cope with chronic diseases and its treatment. For the elderly study participants, family members were responsible for helping with the needs and care of their pathologies, but mostly for supplying their affective needs. In $20 \%$ of the discourses, participants reported little or no contact with their family members, given the distance or lack of interest.

Some study participants (45\%) reported being inserted into the religious community, attending with regular frequency masses, church meetings, etc., while others who have a declared religion, participated in religious activities of other religions, showing the Brazilian religious syncretism.

\section{Lifestyle}

This thematic unit identified two units of record: food and limitations/aggravation.

\section{a) Food}

The control of sodium intake is one of the measures necessary to maintain blood pressure levels within the normal range. ${ }^{(6)}$

Eating habits directly depend on the culture of people, for many patients, food rich in sodium and fat is considered adequate food, food "that sustains" and that the diet required for the control of chronic disease is "poor food" that sickens. Making it difficult for health professionals to achieve adherence to a healthier eating lifestyle, which is necessary for the control and treatment of diseases such as diabetes, hypertension and dyslipidemia.

The cultural aspect should be considered in the care planning in order to minimize resistance to the new dietary counseling of the patient and facilitate the creation of alternatives for a dietary reeducation.

\section{b) Limitations/Aggravation}

Regular physical activity is important for the prevention of chronic non-communicable diseases, but also for the prevention of aggravation resulting from these conditions to promote health and quality of life during the aging process. $^{(7)}$

According to a research conducted in Brazil, it is estimated that $10 \%$ of people over 65 years need help to perform some basic self-care activities, and $40 \%$ of Brazilians with this age depend on help to perform instrumental activities of daily living. ${ }^{(8,9)}$

Elderly who experienced the decline in their ability to self-care, relying on family members caused a negative impact on quality of life, being a factor that generated anxiety and other negative feelings.

\section{Emotional impact}

Chronic disease and the limitations brought by disease also brought negative feelings and emotional distress for the elderly participants.

Chronic diseases and decreased functionality significantly affected the quality of life of the elderly, as breaking the continuity of lifestyle and requiring the use of coping methods. ${ }^{(10)}$

Limitations brought by chronic diseases tend to compromise the self-evaluation, reducing their potential to experience life in a positive way. ${ }^{(11)}$

For $30 \%$ of elderly participants, chronic diseases led to growing dependence and significant reduction of autonomy in basic and complex activities of daily living, it was always reported in the context of psychological suffering, anguish and consequent decline in quality of life.

\section{Socioeconomic Impact}

Receiving a diagnosis of a chronic disease and adapting one's life to it can interfere with the family's financial situation negatively.

For some study participants, chronic disease led to early retirement and other elderly financial situations prevent the performance of leisure activities such as tours and trips.

Retirement represents a decrease in the standard of living due to salary reductions. Medicine expenses and medical expenses may become burdensome for the elderly. In Brazil, it is estimated that half of the elderly have less than or equal to the minimum wage as personal income and average monthly spending on medications of about a quarter of the income (23\%) from half of the elderly Brazilian population. ${ }^{(12,13)}$

\section{COPING}

Coping is defined as a set of strategies used to cope and adapt to the adversities of life. ${ }^{(14,15)}$ 
In this central theme, three thematic units were defined: personal coping, social support and spirituality. Several participants in the study reported more than one coping strategy, which is expected when facing some serious health aggravation, but they are presented separately in this study, for better visualization and analysis.

\section{Personal coping}

This thematic unit analyzed the discourses that show the strength of individual will and belief in yourself, understood in this study as personal coping.

Several participants reported critical life experiences in which their own willpower led them to overcome barriers.

It is important to appreciate the inner strength and resilience of the elderly and in chronically ill patients in general. Health professionals should identify potential deficits of individual coping with their patients and understand that resilience is key to better management of chronic disease and its consequences. Thinking beyond chronic diseases, those who are more resilient are more prepared to face any crisis that can happen in life of every individual and hence have a better quality of life, irrespective of diseases, impairment and other situations that generate stress and negative feelings.

\section{Social Support}

\section{a) Support}

In pursuit of greater coverage of spirituality, an approach was about "the meaning of life" and the most recurrent answer was family.

In the current context of high prevalence of chronic diseases and the epidemiological transition, families are increasingly taking responsibility for the health care of the elderly with chronic conditions, supporting the care until full recovery or when this does not happen, with the disease and its sequels. ${ }^{(16-18)}$

Aging and chronic disease cause many losses to the elderly, such as loss of autonomy and reduced quality of life. The social support of the elderly is very important to facilitate their adaptation of this coping process. The social resources help protect the elderly from negative feelings, depression and stress. ${ }^{(19-21)}$

The feeling of belonging to individuals within the family environment is important for good psychological health and quality of life.

Aside from family, social support can be offered by friends and colleagues of activity as groups of seniors and promotes positive feelings, also establishing a coping strategy. ${ }^{(22)}$

Unfortunately, many elderly do not have a network of minimal social support, and end up suffering from abandonment and distance from family.

\section{b) Abandonment}

The family is the first reference of socialization of the elderly when there is an absence or disruption of this insertion, the elderly feels ignored, devalued, excluded. This relation depends primarily on the bonds that were established during the life and strength of these relationships. ${ }^{(23)}$

\section{Spirituality}

Spirituality is manifested in the life of human beings in infinite ways that vary according to age, religion, culture and health state. In order to understand the role of spirituality in the lives of elderly participants, all reports were considered in their integrality, not restricting the analysis only to health issues.

The concept of spirituality used in this research was spirituality as the meaning of life. ${ }^{(24)}$ Participants answered the question: What gives meaning to your life? And from these responses we analyzed the content and defined the units of record as the following.

For the analysis of this central theme, three units of record were defined: increased spirituality, conserved spirituality and decreased spirituality:

\section{a) Increased spirituality}

In the discourses resulted from the interviews, spirituality appeared in critical situations of health problems, helping the individual to have serenity and optimism. In moments like the death of a loved one, breakup, illnesses and limitations, spirituality contributes to the growth and maturation of the human being. ${ }^{(22,25)}$

In case of illness, pain and terminal illness, other questions are made by patients, such as "why me?", "What happens after my death?", and it is through their personal beliefs that the individual can find serenity to deal with the absence of answers, hope and optimism to face the disease. For participants in this study, these beliefs were generating feelings of relief. ${ }^{(26,27)}$

Spirituality is a way of meaning loss, and thus personal beliefs help in coping with grief and acceptance of death. Having a "good relationship" with God or higher entity, regardless of the religion practiced by the individual, promotes understanding of human suffering. ${ }^{(28,29)}$

Spirituality has great potential to alleviate suffering from conflict as reported by patients in this study, not always the relationship between physical and emotional health, and individuals' beliefs is identified and valued by health professionals in everyday practice, despite numerous benefits that have been discussed in the scientific field.

\section{b) Spirituality}

For the analysis, we considered the conserved spiritu- 
ality among elderly who reported faith in God and spirituality in the meaning of their lives and did not seek it only in critical moments.

The impact of coping with critical situations happen when the spirituality of the individual is part of their values, ideals and most intimate beliefs, and thus it is applied to their daily lives.

Apart from spirituality, the act of praying may mobilize positive energies for the process of coping and disease management. The practice of praying is beneficial in many ways, as well as requests to God, often prayers of thanksgiving are made, generating feelings of gratitude for life, health, family and etc. ${ }^{(30)}$

Regardless of reported religion, elderly who have a good relationship with a "higher entity" also have greater resilience to face life's barriers and situations of suffering, seeing life more positively and optimistically.

\section{c) Decreased Spirituality}

Spirituality and religiosity are not necessarily present in people's lives, beliefs, values and ideals are very intimate aspects and depend on each individual's perception of his/her life and the environment around him/her.

In the present study sample, there were no participants who did not belong to any religion or who did not believe in God's existence. Nevertheless, there were discourses in which faith was not cited as a positive mechanism to face difficulty and did not confer benefits to their faith.

\section{EXPECTATIONS}

When we talked about the sense of hope and optimism generated by coping mechanisms discussed above, it was observed, as a result of this study, that expectations regarding the treatment and family and personal satisfaction are part of the management of chronic disease for the elderly participants.

\section{Expectations regarding health}

Expectations of improvement with treatment, and hope to continue living were present in the discourses of the participants. For one of the participants, believing that God would heal him meant that he did not have to adhere to the prescribed surgical treatment. For several other participants, improvements resulting from treatment for pathology were better reasons for satisfaction with life.

Enhancing the treatment and the improvements is important to the person with chronic disease, so that he/she has a good adherence to lifestyle changes necessary to control the disease. ${ }^{(22)}$ Experiencing the improvement of symptoms such as pain, for example, is one of the main factors favoring adherence of patient to drug treatment.

\section{Expectations regarding the meaning of life}

In the discourse of some participants (15\%), expectations that the elderly had, were cited as the meaning of their lives. For many of them, seeing the success of their children was great satisfaction in life.

The family life cycle is permeated by different expectations, it is expected that parents have expectations for their children's future. Occasionally, and depending on the emotional structure of the family, chronic disease negatively affects these plans.

For some study participants, the act of helping family, neighbor, doing charity and volunteer work was referred to as part of the meaning of life and important expectation for the future.

Defining spirituality as "what gives meaning to life" opens up a range of meanings for what the individual considers important to their existence and where they can find motivation to move on. For some study participants, expectations for the future were responsible for giving meaning to life, and were expectations of helping families and individuals in need. ${ }^{(30)}$

In countless ways spirituality/religiousness/faith interfere positively in addressing the barriers and difficulties of life and strengthen the resilience, improving their quality of life and control of their chronic disease. Health professionals should be alert in order to encourage and promote education and accountability measures of treatment.

\section{FINAL CONSIDERATIONS}

For professionals working in public health to obtain the patient's adherence to treatment and re-educate them to a healthy lifestyle is a constant challenge. Brazil is a country of continental dimensions, where migrations are intense and, consequently, the culture becomes mixed, as its population. The cultural context of the chronic patient interferes directly in relation with the disease and treatment.

The cultural context, beliefs and values influence patient adherence or non-adherence to treatment for chronic disease. The chronic disease causes significant impact on the lifestyle of the patient and requires an active effort so that the management of this new condition is effective.

In this study, subjectivity present in the impact of the diagnosis of chronic disease and ways of coping used by patients became evident.

Numerous contents of the discourses of the participants emerged, but despite its classification as central themes, thematic units and units of record, all categories are interrelated when reported by the elderly, highlighting the subjective nature of the topic, in which feelings, expectations and anxieties mix in the context of the participant. 
Having a chronic disease changed the lifestyle of study participants, requiring changes in diet and bringing limitations and aggravation that have undermined the autonomy of the elderly, implying negative feelings in performing basic and instrumental activities of daily living. This impact on independence of patients related to the emotional aspect of these elderly, because for most of them, dealing with the limitations resulting from chronic diseases was a factor that generated suffering, anguish and sadness, having significant negative impact on quality of life.

The main aspect to be considered is coping with limitations and control of chronic disease. The data revealed an individual way of coping, in which the inner strength of patients stimulates self-care and accountability for the management of pathology.

From the perspective of the concept of spirituality as giving "meaning to life", the family was reported as the meaning of existence for many participants in the study, highlighting the importance of the presence of family members in the social context of the elderly, patients with or without chronic disease.

Social support from family and friends favors patients when facing difficulties, because it is finding meaning to life that the elderly overcome critical moments and without this kind of belief, suffering and existence does not make sense. Unfortunately, elderly do not always have this kind of family support and end up suffering from abandonment.

Following the idea of "meaning of life", the analysis of conserved spirituality, we considered the elderly who reported their beliefs as the meaning of their existence and have not sought faith or just more intensely in times of difficulties. Participants who reported regular participation at Masses, worship and religious gatherings also obtained benefits of social support received by living in these environments.

\section{REFERENCES}

1. Craig C, Weinert C, Walton J, Derwinski-Robinson B. Spirituality, Chronic Illness, and Rural Life. J Holist Nurs. 2006;24(1):27-35.

2. Oman D, Thoresen CE. Does religion cause Health? Differing interpretations and diverse meanings. J Health Psychol. 2002;7(4):365-380.

3. Panzini RG, Rocha NS, Bandeira DR, Fleck MPA. Qualidade de vida e espiritualidade. Rev Psiq Clin. 2007;34(1):105-155.

4. Koenig HG. Suicide in the elderly: Case Discussion. South Med. 2006;99(10):1188.
Beyond spirituality, praying mobilizes positive energies for the coping process, prayers of thanksgiving promote feelings of gratitude for life and generate positive feelings of well-being and relaxation. Belonging to a particular religion is not what defines the benefits or losses of spirituality, while having a "good relationship with a Higher entity of their belief is what strengthens the resilience of the elderly.

Although all participants declare themselves belonging to a religion, for some study participants, faith offered no benefits in coping, and religious practice did not promote social interactions and social support.

Regarding expectations in health, God appears with the health provider and $\mathrm{He}$ is cited as the most important aspect of life. For these patients, faith helps in treatment adherence and practice of self-care. The act of helping families, helping others, to practice charity and volunteer work have also been referred to as part of the meaning of life, and important expectation for the future.

Health teams engaged in assisting elderly people with chronic diseases should have the sensitivity to understand the elderly within their cultural context and facilitate understanding and accountability of the patient and their condition.

The definitions of spirituality become large when analyzing the subject in this light, broad approaches regarding this theme may also be conducted by nursing and the health professional in general. Studies with spirituality in Brazil are gaining ground in scientific field and should be taken into clinical practice in order to ensure a holistic care to our patients, regardless of disease, chronic or acute, and regardless of age, from children to elderly.

5. Martins LM, França APD, Kimura, M. Qualidade de vida de pessoas com doença crônica. Rev Lat Am Enfermagem. 1996;4(3):5-18.

6. Molina MCB, Cunha RS, Herkenhoff LF, Mill JG. Hipertensão arterial e consumo de sal em população urbana. Rev Saude Pública. 2003;37(6):743-50.

7. Matsudo SM, Matsudo VKR, Neto TLB. Atividade física e enveIhecimento: aspectos epidemiológicos. Rev Bras Med Esporte. 2001;7(1):2-13.

8. Barros MBA, César CLG, Carandina L, Torre GD. Desigualdades sociais na prevalência de doenças crônicas no Brasil, PNAD-2003. Cien Saúde Colet. 2006;11(4):911-926. 
9. Karsh UM. Idosos dependentes: famílias e cuidadores. Cad Saúde Pública. 2003;19(3):861-866.

10. Rabelo DF, Neri AL. Recursos psicológicos e ajustamento pessoal frente a incapacidade funcional na velhice. Psicol Estud. 2005;10(3):403-412.

11. Smith J, Borchelt M, Maier H, Jopp D. Health and well-being in the young and oldest old. Journal of Social Issues. 2002;58(4):715-732.

12. IBGE. Fundação Instituto Brasileiro de Geografia e Estatística, 1998. Pesquisa Nacional por Amostra de Domicílios. Rio de Janeiro: IBGE.

13. Lima-Costa MF, Barreto SM, Giatti L. Condições de saúde, capacidade funcional, uso de serviços de saúde e gastos com medicamentos da população idosa brasileira: um estudo descritivo baseado na Pesquisa Nacional por Amostra de Domicílios. Cad Saúde Pública. 2003;19(3):735-743.

14. Antoniazzi AS, Dell'Aglio DD, Bandeira DR. O conceito de coping: uma revisão teórica. Estudos de Psicologia. 1998;3(2):273-294

15. Savoia MG. Escala de eventos vitais e estratégias de enfrentamento (Coping). Revista de Psiquiatria Clínica. 1999;26(2).

16. Marcon SS, Radovanovic CAT, Waidman MAP, Oliveira MLF, Sales CA. Vivências e reflexões de um grupo de estudos junto às famílias que enfrentam a situação crônica de saúde. Texto Contexto Enferm. 2005;14(Esp):116-124.

17. Oliveira TC, Araújo TL. Mecanismos desenvolvidos por idosos para enfrentar a hipertensão arterial. Rev Esc Enferm USP. 2002;36(3):276-281.

18. Silva, LF, Guedes, MVC, Moreira, RP, Souza, ACC. Doença Crônica, o enfrentamento pela família. Acta Paul Enf. 2002;15(1):40-47.

19. Guedes MTD, Albuquerque FJB, Tróccoli BT, Noriega JAV, Seabra MAB, Guedea RLD. Relação do bem-estar subjetivo, estratégias de enfrentamento e apoio social em idosos. Psicologia: Reflexão e Crítica. 2006;19(2):301-308.
20. Gomes-Villas Boas, LC. Apoio social, adesão ao tratamento e controle metabólico de pessoas com diabetes mellitus tipo 2 [dissertação]. Ribeirão Preto: Escola de Enfermagem de Ribeirão Preto, Universidade de São Paulo; 2009.

21. Sena RR, Silva KL, Rates HF, Vivas KL, Queiroz CM, Barreto FO. O cotidiano da cuidadora no domicílio: desafios de um fazer solitário. Cogitare Enferm. 2006;11(2):124-132.

22. Trentini M, Silva SH, Valle ML, Hammersdmidt KSA. Enfrentamento de situações adversas e favoráveis por pessoas idosas em condições crônicas. Rev. Lat. Am. Enfermagem. 2005; 13(1):38-45.

23. Herédia VBM, Cortelletti IA, Casara MB. Abandono na velhice. Textos Envelhecimento 8(3), 2005.

24. Hunter JC. O monge e o executivo. Rio de Janeiro: Sextante, 2004.

25. Batista PSS. A espiritualidade na prática do cuidar do usuário do Programa Saúde da Família, com ênfase na educação popular em saúde. Revista APS. 2007;10(1):74-80.

26. Nascimento LC, Rocha SMM, Hayes VH, Lima AG. Crianças com câncer e suas famílias. Rev. Esc. Enferm. USP. 2005;39(4):469-474.

27. Puchalski C. Spirituality in health: the role of spirituality in critical care. Crit Care Clin. 2004;20:487-504.

28. Araújo MMT. Quando "uma palavra de carinho conforta mais que um medicamento": necessidades e expectativas de pacientes sob cuidados paliativos [dissertação]. São Paulo: Escola de Enfermagem. Universidade de São Paulo; 2006.

29. Elias ACA, Giglio JS. Sonhos e vivências de natureza espiritual relacionados à fase terminal. Mudanças - Psicologia da Saúde. 2002;10(17):83-106.

30. Rocha ACAL. A Espiritualidade no manejo da doença crônica do idoso [dissertação]. São Paulo: Escola de Enfermagem. Universidade de São Paulo; 2011. 